\title{
Regulatory Authority
}

National Cancer Institute

\section{Source}

National Cancer Institute. Regulatory Authority. NCI Thesaurus. Code C88081.

A geopolitical organization responsible for regulating products used in health care. 